\title{
THE USE OF MARINE SHELLS FOR RADIOCARBON DATING OF COASTAL DEPOSITS
}

\section{FRANCISCO HILÁRIO REGO BEZERRA ${ }^{1}$, CLAUDIO VITA-FINZI ${ }^{2}$ AND FRANCISCO PINHEIRO LIMA FILHO ${ }^{1}$}

\begin{abstract}
To facilitate the selection of samples for ${ }^{14} \mathrm{C}$ dating, shells from coastal deposits were analyzed by light microscopy, $\mathrm{X}$-ray diffraction, scanning electron microscopy, and isotope analysis. One or more of these techniques made it possible to detect contamination by old and young carbon and to identify appropriate pretreatment procedures. Microscopic inspection and X-ray analysis are especially useful when applied to aragonitic mollusks as contamination is often calcitic and thus readily detected. Death assemblages, when correctly selected, provide reliable ages for coastal deposits, but in certain circumstances dates determined on these assemblages were found to be superior to dates for tracing shorelines.
\end{abstract}

Keywords: coastal deposit, radiocarbon dating, marine shell, contamination, death assemblage

\begin{abstract}
INTRODUCTION The radiocarbon dating method is widely used in coastal studies throughout the world but precise absolute dating of former shorelines remains a major obstacle. In many paleoshorelines shells are the only readily available biogenic materials for radiocarbon measurements. Two major problems arise in their use: (a) contamination by old carbon produced by the hard water effect, leading to ${ }^{14} \mathrm{C}$ ages which are too old, and contamination by young carbon, in the form of overgrowths and recrystallization, leading to ages which are too young; (b) the need to select an appropriate sealevel indicator. Several studies (e.g., Oliveira et al. 1990), often supported by numerous ${ }^{14} \mathrm{C}$ ages, have described changes in sea level that have taken place during the Quaternary along the east coast of South America, but little information is available on (a) the extent of contamination and (b) the palaeoecology of the marine shells used for ${ }^{14} \mathrm{C}$ analysis. This study discusses the problem, using examples from northeastern Brazil. It reviews some of the methods that can be used to detect and reduce or eliminate the effects of contamination, and compares ages of shells in living position with death assemblages to search former waterlines.
\end{abstract}

COASTAL SETTING The study area is located along the Rio Grande do Norte State coast between Macau and Baia Formosa (Fig. 1 ). The littoral zone includes a great variety of shallow-water marine deposits (beachrock, peat, and tidal flats) all of which locally interfinger with alluvial and aeolian sediments. Death assemblages of shells and shells in living positions tend to be concentrated in deposits close or in the current intertidal zone. The most common shell species from shallow-marine waters, in order of abundance, are Donax striata, Divaricella quadrisulcata, Tivela mactroides, Anamalocardia brasiliana, Anadara ovalis, and Ostrea sp. (Mendonça 1966, Campos and Silva 1964). Seven intertidal deposits (one tidal flat, one peat, and five beachrock deposits) were investigated. Shells were in living position in the Rio do Fogo peat. Death assemblages of shells were found in the other sites. The locations and cross-sections of each deposit are shown in figure 1.

\section{PROBLEMS RELATED TO SHELL AND COASTAL-} DEPOSIT DATING One of the problems that can arise in radiocarbon dating of marine shells is contamination by old carbon. Shells may incorporate dissolved carbon dioxide or bicarbonates from "old" and deep ocean waters that are not in equilibrium with the atmosphere (reservoir effect), or from limestone areas (hard water effect).

The reservoir effect has been detected in many coastal areas around the world and is generated by upwelling from deep oceans which display low mixing ${ }^{14} \mathrm{C}$ rates with the atmosphere (Bowman 1990). Studies such as those by Keith et al. (1964) and Taylor and Slota (1979) conclude that marine shells from open ocean environments, where upwelling and carbon isotopes ratios are known, display small variations of $\mathrm{d}^{13} \mathrm{C}$ and can provide reliable ${ }^{14} \mathrm{C}$ ages.

The hard water effect is usually associated with continental contamination and, according to Pilcher (1991), may add between 200 and 1200 years to the apparent age of a sample. The effect is more critical in terrestrial mollusks, which usually occur in restricted environments and may be contaminated by significant amounts of carbon from carbonate rocks (Hedges 1992). In open coastal zones, especially if there is no restriction in water circulation, marine shells are not likely to suffer appreciably from the hard water effect.
Shells ages may be rendered too young when they are contaminated by carbon added to the original material by overgrowth and recrystallization, a common source on the coast being percolating groundwater.

Another problem in coastal studies is the choice of sea-level indicator. Keith et al. (1964) suggested that only shells in living positions should be dated and that beach deposits should be avoided because they are likely to include specimens of different ages and from a range of environments. Hopley (1986) pointed out that the time difference between shell death and its deposition in a beach may vary from a few years to hundred or even thousands of years. Nevertheless, as Richards (1982) noted, shells in living positions are poor guides to former sea level if their preferred habitat is not known or if they have a wide depth tolerance, whereas death assemblages can be good shoreline indicators if they represent the high-water mark.

PRETREATMENT AND SHELL ANALYSIS Pretreatment was designed to detect and if necessary eliminate contamination. Shells in living position and death assemblages were selected for analysis. When selecting the latter, we sorted out shells that showed original colors and lacked any features to be expected from prolonged transportation. Several studies had demonstrated that, although the outer layer of shells exchange carbon with the environment during diagenesis, the inner layer can be considered a closed system (e.g., Vita-Finzi 1980, Vita-Finzi and Roberst 1984). Chappell and Polach (1972) show that detailed analysis of shell structure under the microscope was essential to valid assessment of replacement. We began our screening with optical microscopy, generally using acetate peels rather than thin sections because they preserve fine detail. If any suspected features were found, or if the sample came from a location where contamination is a serious risk, we used X-ray diffraction-XRD, scanning electron microscopy-SEM and stable isotope analysis (Fig. 2) either of a subsample of the shell or of an aliquot of the gas prepared for counting. If the contamination was at the surface, we tried to remove it mechanically or by acid washes and then reassess the specimen. If the contamination was too serious or difficult to remove we discarded the sample (see samples SM1 and SM2, Table 1), although if no alternative material was to hand we dated the sample in the knowledge that it will provide a minimum age.

Note that contamination of aragonitic material is readily detected by $\mathrm{X}$-ray diffraction in aragonitic shells because the contaminant is usually calcitic; in calcitic shells (such as oysters) the procedure succeeds only if the new calcite differs sufficiently in magnesium content for the peak on the trace to be displaced relative to that of the original shell calcite.

Radiocarbon ages of shells quoted in this study (Table 1) are from Bezerra (1998), Bezerra et al. (1998) and Oliveira et al. (1990), whereas isotopic analyses of the same samples (Table 2) are new data. Isotopic analysis was carried out on shells both to check the reliability of the ${ }^{14} \mathrm{C}$ ages and for paleoenvironment purposes. The samples were run at the Department of Geology, Royal Holloway and Bedford New College (University of London), using a VG ISOCARB automatic system and VG SIRA II collector spectrometer. The precision of the system for $\mathrm{C}$ and $\mathrm{O}$ is $0.1 \%$ for $2 \mathrm{SD}$.

DISCUSSION AND CONCLUSION Analysis carried out during pretreatment and isotopic measurements allowed us to identify two main ${ }^{14} \mathrm{C}$ age groups: contaminated or inherited shell ages which 


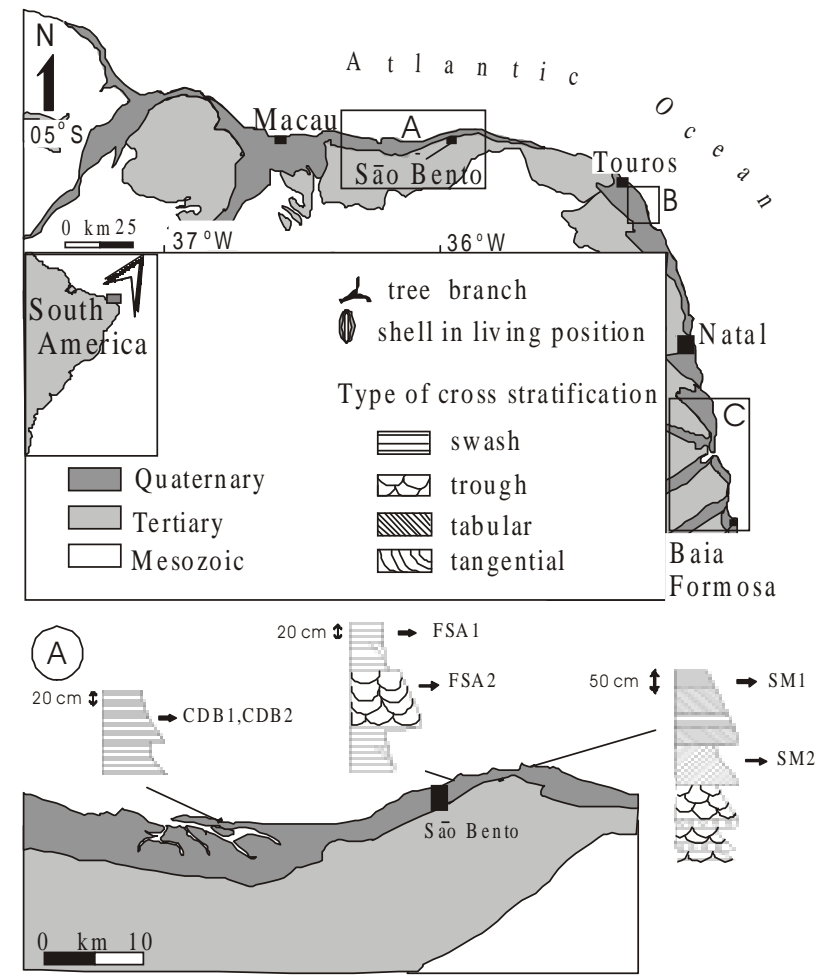

(B)

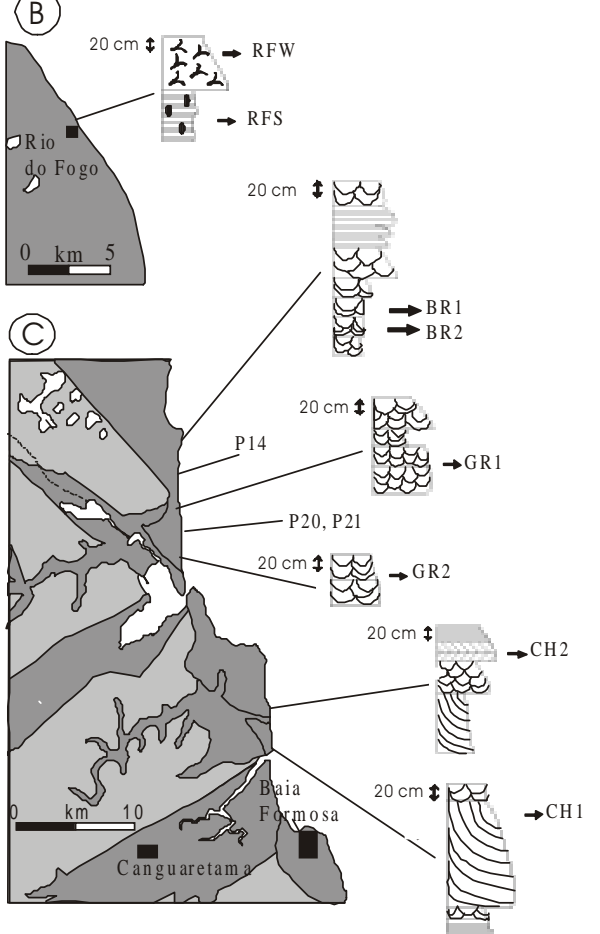

Figure 1 - Simplified geological map of the study area. Detailed maps that include cross-sections of coastal deposits described in text are indicated by letters $A, B$, and $C$.

were younger or older than the host deposit; and shell ages that represent the age of the deposit and, by extension, the paleoshoreline.

The isotopic data were helpful to distinguish shells that had not been transported from continental shelf or from the continent. The shells in Fig. 2 display a small isotopic range. The $d^{13} \mathrm{C}$ values extended from $+0.8 \%$ o to $-2.4 \%$, and $\mathrm{d}^{18} \mathrm{O}$ values extended from $0.0 \%$ o to $+1.2 \%$. The shell assemblage plot partially in the $\mathrm{F}$ field (marine coastal shells of Vita-Finzi 1992) and entirely in the A and B fields (mollusk shells of transitional environment of Keith and Parker 1965). None of the marine shells from the study area is displaced towards the freshwater, continental shell fields (fields D and E in Fig. 2), ruling out
Table $1-{ }^{14} \mathrm{C}$ ages of shells discussed in text.

\begin{tabular}{|c|c|c|c|}
\hline $\begin{array}{l}\text { Sample/ } \\
\text { source }\end{array}$ & $\begin{array}{l}\text { Species/material } \\
\text { analysed/deposit }\end{array}$ & $\begin{array}{l}\text { XRD/ } \\
\text { SEM }\end{array}$ & $\begin{array}{l}\text { Calibrated age } \\
\text { (yr BP at } 2 \sigma \text { ) }\end{array}$ \\
\hline MC2/1 & ls & ---- & modern \\
\hline CDB1/1 & $\mathrm{b} / \mathrm{da} / \mathrm{tf}$ & A & $\begin{array}{r}3,930^{+320} \\
-290\end{array}$ \\
\hline CDB2/1 & $\mathrm{o} / \mathrm{da} / \mathrm{tf}$ & $\mathrm{C}$ & $\begin{array}{c}4,710^{+280} \\
-340\end{array}$ \\
\hline FSA1/1 & $\mathrm{b} / \mathrm{da} / \mathrm{b}$ & A & $\begin{array}{c}6,460^{+430} \\
-390\end{array}$ \\
\hline FSA2/1 & $\mathrm{b} / \mathrm{da} / \mathrm{b}$ & A & $\begin{array}{r}7,070^{+360} \\
-490\end{array}$ \\
\hline RFW/2 & $\mathrm{w} / \mathrm{p}$ & --- & $4040-3690$ \\
\hline RFS/1 & $\mathrm{b} / \mathrm{lp} / \mathrm{b}$ & A & $\begin{array}{r}* 4100_{-10}^{+50} \\
\end{array}$ \\
\hline BR1/1 & $\mathrm{b} / \mathrm{da} / \mathrm{b}$ & A & $\begin{array}{r}4,880^{+420} \\
-320\end{array}$ \\
\hline BR2/1 & $\mathrm{b} / \mathrm{da} / \mathrm{b}$ & A & $\begin{array}{c}4,710^{+260} \\
-320\end{array}$ \\
\hline GR1/1 & $\mathrm{b} / \mathrm{da} / \mathrm{b}$ & A & $\begin{array}{r}5,970_{-350}^{+380} \\
-350\end{array}$ \\
\hline GR2/1 & $\mathrm{b} / \mathrm{da} / \mathrm{b}$ & A & $\begin{array}{r}7,070^{+360} \\
-500\end{array}$ \\
\hline $\mathrm{CH} 1 / 1$ & $\mathrm{~b} / \mathrm{d} / \mathrm{b}$ & A & $\begin{array}{c}7,070_{-490}^{+360} \\
-490\end{array}$ \\
\hline $\mathrm{CH} 2 / 1$ & b/da./b & $\mathrm{A} / \mathrm{sC}$ & $\begin{array}{r}5,750^{+420} \\
-330\end{array}$ \\
\hline $\mathrm{P} 20 / 3$ & $\mathrm{~b} / \mathrm{da} / \mathrm{b}$ & --- & $\begin{array}{r}6,490^{+200} \\
-190\end{array}$ \\
\hline $\mathrm{P} 21 / 3$ & $\mathrm{~b} / \mathrm{da} / \mathrm{b}$ & --- & $\begin{array}{r}6,370^{+230} \\
-200\end{array}$ \\
\hline $\mathrm{P} 14 / 3$ & $\mathrm{~b} / \mathrm{da} / \mathrm{b}$ & --- & $\begin{array}{r}4,970_{-330}^{+340} \\
-330\end{array}$ \\
\hline
\end{tabular}

Source: (1) Bezerra et al. (1998); (2) Bezerra (1998); (3) Oliveira et al. (1990). (*) yr BP at 16. Radiocarbon analysis after Vita-Finzi (1983). Key: ls, live shell; b, bivalve; da, death assemblage; $t f$, tidal flat; $o$, ostrea; $b$, beachrock; $w$, wood; p, peat; lp, living position; A, aragonite; $C$, calcite; $s C$, secondary calcite.

Table 2 - Isotopic data discussed in text.

\begin{tabular}{|lccc|}
\hline sample & $\begin{array}{c}\text { Material analysed/ } \\
\text { deposit }\end{array}$ & $\delta^{13} \mathrm{C}_{\mathrm{PDB}}(\%$ o $)$ & $\delta^{18} \mathrm{O}_{\mathrm{PDB}}(\% o)$ \\
\hline CH1 & $\mathrm{da} / \mathrm{b}$ & -2.2 & -0.8 \\
$\mathrm{FSA} 1$ & $\mathrm{da} / \mathrm{b}$ & -1.2 & -0.4 \\
$\mathrm{FSA} 2$ & $\mathrm{da} / \mathrm{b}$ & -0.7 & -0.5 \\
$\mathrm{RFS}$ & $\mathrm{lp} / \mathrm{p}$ & -1.5 & -0.8 \\
$\mathrm{BR} 1$ & $\mathrm{da} / \mathrm{b}$ & -1.3 & -0.9 \\
$\mathrm{BR} 2$ & $\mathrm{da} / \mathrm{b}$ & -1.3 & -0.9 \\
$\mathrm{CDB} 1$ & $\mathrm{da} / \mathrm{tf}$ & -1.6 & -0.8 \\
$\mathrm{CDB} 2$ & $\mathrm{da} / \mathrm{tf}$ & -1.3 & -0.3 \\
$\mathrm{CH} 2$ & $\mathrm{da} / \mathrm{tf}$ & -0.8 & -0.7 \\
\hline
\end{tabular}

Key: da, death assemblage; $b$, beachrock; lp, shell in living position; $p$, peat; $t d$, tidal flat.

any continental influence in shell composition. This is consistent with the unrestricted ocean circulation in the study area, and thus appears to exclude the hard water effect.

The activity determined for a specimen collected live (MC2), one count per minute (cpm) above the pre-bomb level of 7.7 above background (Bezerra et al. 1998), shows that the residual effect of the atmospheric bomb test swamps any apparent reservoir effect within the resolution of the method. Likewise, any reservoir effect, which was swamped, by the bomb effect, is ruled out by the isotopic data. XRD analyses indicated that some of the samples that appeared satisfactory under the light microscopy include the products of recrystallization 


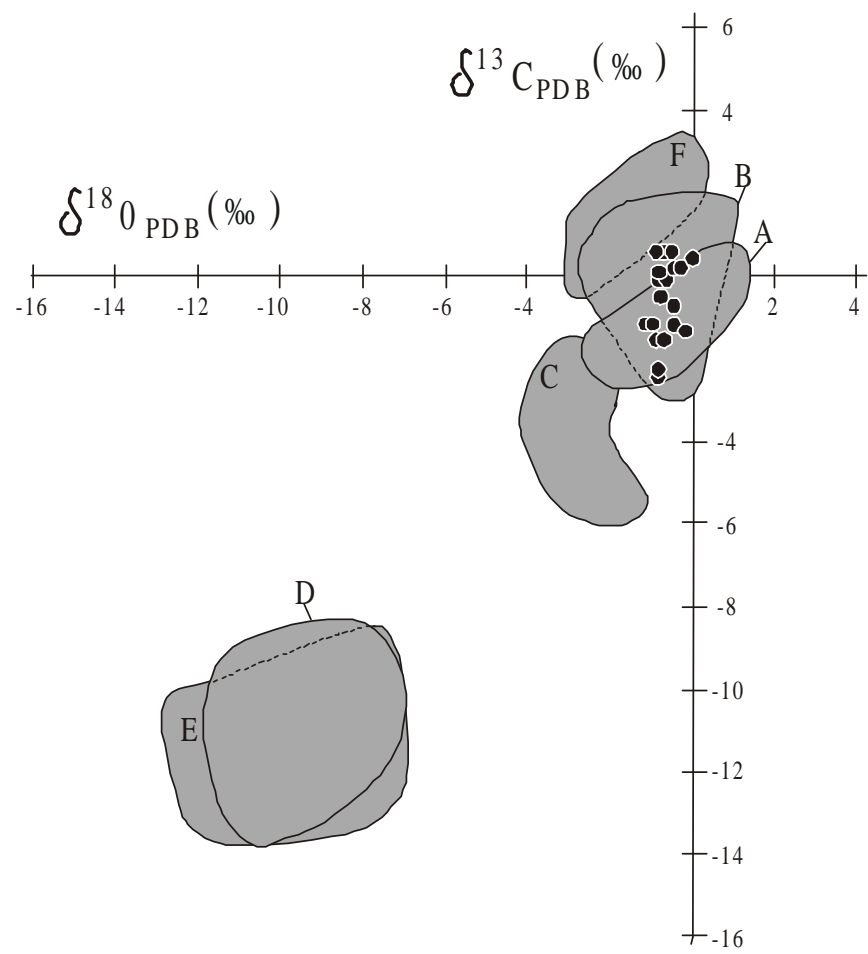

Figure 2 - Stable isotope composition of mollusk shells. Key: A, B, Cmollusk shells of transitional environment (Keith and Parker 1965); D freshwater mollusks (Keith et al. 1964); E-freshwater gastropods (Keith and Parker 1965); F-marine coastal shells (Vita-Finzi 1992).

from aragonite to calcite: to a significant extent in the Cunhaú beachrock and by trace amounts in the Barreta beachrock. In the Cunhaú beachrock, two samples $(\mathrm{CH} 1, \mathrm{CH} 2)$ were collected at two different locations in the same beachrock body (Fig 1). XRD shows that $\mathrm{CH} 1$ consists wholly of aragonite, whereas $\mathrm{CH} 2$ contains secondary calcite. This explain the age difference between the former $(7070+360-490)$, which is a minimum age of the deposit, and the latter (5750+420-330), which is contaminated by young carbon (Table 1$)$. In the Barreta Beachrock, two other samples were collected at the same site, in a layer of uniform structures and granulometry (BR1 and BR2, Fig. 1). BR1 (upper sample) is older than BR2 (lower sample), which shows trace of secondary calcite (Table 1 ). If we take into account the date published by Oliveira et al. (1990) for the same beachrock (P14), the date of deposition falls between 4640-4970 cal. yr. BP.

In the Catanduba tidal flat, which is located $\sim 6 \mathrm{~km}$ from the current shoreline (Fig. 1), sample CDB1, consisting of aragonitic bivalve shells, and CDB2, composed of calcitic Ostrea, were collected in the same layer. There is a gap of $120 \mathrm{yr}$. between the samples, probably because the Ostrea assemblage is redeposited.

Ages of death assemblages represent age of deposition in two beachrocks. In the Farol de Sto. Alberto beachrock, two samples were dated by Bezerra et al. (1998). The mean age of the lower sample FSA2 is $\sim 600$ yr. older than the upper sample FSA1. However, there is a small age superposition between both samples from 6030-6580, which is probably the deposit's age. There is also the possibility that FSA2 is really older than FSA1. There is no age superposition between samples GR1 and GR2 in the Guaraíra beachrock. As no contamination was seen during visual inspection, XRD, and SEM, the beachrock should have a deposition which spans from $~ 7070$ to 5970 cal. yr. BP. This is in agreement with several cycles of deposition seen in cross-section (Fig. 1).

In summary, it is essential to guard against contamination by old carbon (hard water and reservoir effect) and young carbon (overgrowth and recrystallization). The former can be detected by isotopic analysis, whereas problems produced by contamination by young carbon may be apparent under the light or scanning electron microscope or using $\mathrm{X}$-ray diffraction, and reduced or eliminated by selective mechanical abrasion and acid leaching. In certain circumstances ages on shells from death assemblages are more useful than ages on shells in living position for tracing shifts in the coastline.

\section{References}

Bezerra F.H.R. 1998. Neotectonics in Northeastern Brazil. University of London, London, Ph.D. Thesis, $208 \mathrm{p}$.

Bezerra F.H.R.; Lima-Filho F.P.; Amaral R.F.; Caldas L.H.O; Costa-Neto L.X. 1998. Holocene coastal tectonics in NE Brazil. In: Stewart I. and Vita-Finzi C. (eds.) Coastal Tectonics. London, Geological Society Special Publications, 146:279-293.

Bowman S. 1990. Interpreting the past-Radiocarbon Dating. London, The British Museum Publications Ltd., 64 p.

Campos e Silva A. 1966. Considerações sobre o Quaternário do Rio Grande do Norte. Archaeology Institute of the Federal University of Rio Grande do Norte state, 2:275Arch 301.

Chappell J.; Polach H.A. 1972. Some effects of partial recrystallisation on ${ }^{14} \mathrm{C}$ dating of late Pleistocene corals and molluscs. Quaternary Resaerch, 2:244-252.

Hedges R.E. 1992. Sample treatment strategies in Radiocarbon dating. In: Taylor R.E.; Long A.; Kra R.S. (eds.) Radiocarbon after four Decades. New York, Spring-Verlag, 165183.

Hopley D. 1986. Beachrock as sea-level indicator. In: O. van de Plassche (ed.). Sea-leve Research: a manual for collection and evaluation of data. GeoBooks, 157-173.

Keith M.L.; Anderson G.M.; Eicher R. 1964. Carbon and oxygen isotopic composition of selected limestones and fossils. Geochimica and Cosmochimica Acta, 28:17571786.

Keith M.L. \& Parker R.H. 1965. Local variations of ${ }^{13} \mathrm{C}$ and ${ }^{18} \mathrm{O}$ content of mollusk shells and their relative minor temperature effect in marginal environment. Marine Geology, 3:83-114.

Mendonça M.I. 1966. O Recife de arenito de Tibau. Archaeology Institute of the Federal University of Rio Grande do Norte state, 2:343-346.
Oliveira M.I.M.; Bagnoli E.; Nogueira A.M.B.; Santiago M. 1990. Considerações sobre a geometria, petrografia, sedimentologia, diagênese e idades dos beachrocks do Rio Grande do Norte. In: SBG, Congresso Brasileiro de Geologia, 34, Natal, Anais, 2:621-634.

Pilcher J.R. 1991. Radiocarbon Dating. In: Smart P.L. \& Frances P.D. (eds.) Quaternary Dating Methods - A user's Guide. Quaternary Research Association Technical Guide, 4:16-36.

Richards G.W. 1982. Intertidal Molluscs as Sea-Level Indicators: A Comparative Study of Modern and Fossil Mediterranean Assemblages. University of London, London,

Taylor R.E. \& Slota P.J. 1979. Fraction studies on marine shells and bone sample for radiocarbon analysis. In: Berger R. \& Suess H.E. (eds.) Radiocarbon Dating. University of California Press, 422-432

Vita-Finzi C. 1980. ${ }^{14} \mathrm{C}$ dating of recent crustal movement in the Persian Gulf and Iranian Makran. Radiocarbon, 22:763-773.

Vita-Finzi C. 1983. First-order 14C dating of Holocene molluscs. Earth and Planetary Science Letters, 65:389-392.

Vita-Finzi C. 1992. Shells, isotopes, and tectonics. Israeli Journal of Science, 41:1-8. Vita-Finzi C. \& Roberst N. 1984. Selective leaching of shells for 14C dating. Radiocarbon, 26:54-58.

Contribution IGC-061

Received February 3, 2000 Accepted for publication April 28, 2000 